\title{
POTENTIAL OF MSWI BOTTOM ASH TO BE USED AS AGGREGATE IN ROAD BUILDING MATERIALS
}

\author{
Audrius VAITKUS, Judita GRAŽULYTË*, Viktoras VOROBJOVAS, \\ Ovidijus ŠERNAS, Rita KLEIZIENĖ
}

\author{
Road Research Institute, Vilnius Gediminas Technical University, Linkmenu g. 28, Vilnius 08217, Lithuania
}

Received 02 October 2017; accepted 29 December 2017

\begin{abstract}
In the European Union, more than 140 million tonnes of municipal solid waste is incinerated annually. It generates about 30-40 million tonnes of residues known as municipal solid waste incinerator bottom ash, which is typically landfilled. To deal with growing landfills, there is a need to utilize municipal solid waste incinerator bottom ash as a building material. It has been known that municipal solid waste incinerator bottom ash properties strongly depend on waste composition, which is directly influenced by people's habits, economic policy, and technologies for metals recovery of bottom ash. Thus, municipal solid waste incinerator bottom ash produced in a specific country or region has primarily to be tested to determine its physical and mechanical properties. The main aim of this study is to determine municipal solid waste incinerator bottom ash physical and mechanical properties (aggregate particle size distribution, water content, oven-dried particle density, loose bulk density, Proctor density, optimal water content, California Bearing Ratio after and before soaking, permeability, Flakiness Index, Shape Index, percentage of crushed and broken surfaces, resistance to fragmentation (Los Angeles coefficient), water absorption and resistance to freezing and thawing). Municipal solid waste incinerator bottom ash produced in the waste-to-energy plant in Klaipeda (Lithuania) was used in this research. Ferrous and non-ferrous metals were separated after more than three months of municipal solid waste incinerator bottom ash ageing in the atmosphere. The study showed promising results from considering municipal solid waste incinerator bottom ash as possible aggregates for road building materials.
\end{abstract}

Keywords: bottom ash, municipal solid waste, municipal solid waste incinerator (MSWI), physical and mechanical properties, road-building material.

\section{Introduction}

According to Eurostat, each inhabitant generates an average of half a tonne of waste per year in the European Union. It is landfilled, incinerated, recycled or composted. Developed countries move steadily towards less landfilling. It results in a larger amount of incinerated, recycled and composted municipal waste. More than 140 million tonnes of municipal waste is incinerated annually. It generates about 30-40 million tonnes of large agglomerated residues, known as municipal solid waste incinerator (MSWI) bottom ash, which is typically landfilled. To deal with growing landfills, there is a need to find alternative ways of utilizing MSWI bottom ash.

Thorough investigations that have been made into the physical and mechanical characteristics of MSWI bottom ash have revealed its potential suitability for civil engineering, especially for road construction. Municipal solid waste incinerator bottom ash is considered suitable as material for embankment and subgrade, binder, granular material for unbound base and sub-base course, fine aggregate replacement in concrete and hot mix asphalt (HMA) (Alhassan \& Tanko, 2012; An et al., 2014; Becquart, Bernard, Abriak, \& Zentar, 2009; Forteza, Far, Seguí, \& Cerdá, 2004; Hassan \& Al-Shamsi, 2010; Hjelmar, Holm, \& Crillesen, 2007; Izquiedro et al., 2001; Ogunro, Inyang, Hooper, Young, \& Oturkar, 2004; Paine, Dhir, \& Doran, 2002; Pecqueur, Crignon, \& Quénée, 2001; Sorlini, Abbà, \& Collivignarelli, 2011; Xie et al., 2017).

Forteza et al. (2004) analysed the physical and mechanical characteristics of MSWI bottom ash such as particle size distribution, particles shape, resistance to fragmentation (Los Angeles coefficient), compactability, bearing capacity (California Bearing Ratio (CBR)), sand

*Corresponding author. E-mail: judita.grazulyte@vgtu.lt 
equivalent and plasticity and showed that bottom ash can be used for embankments, landfillings, base and sub-base courses according to Spanish requirements. The results are similar to the findings of Izquiedro et al. (2001). Alhassan and Tanko (2012) demonstrating that bottom ash is lighter than natural sand and gravel and is thus preferable in places known for low bearing capacity.

The suitability of MSWI bottom ash for cement bound base courses as well as for concrete is questionable according to Spanish requirements, and additional actions such as enhancement of particle size distribution and resistance to abrasion are required. Both are achieved by mixing bottom ash with virgin aggregate (Forteza et al., 2004). Bottom ash suitability for cement bound base courses and concrete is also limited because of the presence of aluminium, which oxidizes and leads to the evolution of hydrogen gas. The gas is entrapped in concrete and creates a network of bubbles, which significantly reduces its strength and durability (An et al., 2014; Müller \& Rübner, 2006). However, if aluminium stability is ensured, bottom ash utilization in concrete is preferable since it minimizes the release of toxic elements into the environment, which is a critical factor considering bottom ash utilization. Paine et al. (2002) revealed that MSWI bottom ash can replace $40 \%$ or even more aggregate in all cement bound materials defined in the United Kingdom Highway Specification. However, in this case (if bottom ash is used for cement bound material production), a larger amount of cement, as well as water, is required.

An et al. (2014) replaced fine aggregate in HMA with $10-40 \%$ of bottom ash, which had the same gradation as the virgin aggregate. Marshall and moisture susceptibility tests indicated that $20 \%$ of bottom ashes is a good candidate for the optimum replacement of fine aggregate in HMA. The same threshold was set considering resistance to rutting and dynamic modulus by Hassan and AlShamsi (2010). In this research, only the passing fraction of $4.75 \mathrm{~mm}$ was used. All studies showed that if bottom ash is used for HMA production, a larger amount of binder is required (An et al., 2014; Hassan, Al-Shamsi, 2010; Ogunro et al., 2004). Ogunro et al. (2004) concluded that $20 \%$ of bottom ash in HMA results in $1.2 \%$ higher binder content and depends on the source of virgin aggregate and bottom ash gradation.

Municipal solid waste incinerator bottom ash characteristics strongly depend on waste composition, which is directly influenced by people's habits and economic policy in the country or region. Thus, MSWI bottom ash produced in a specific country or region cannot be directly used to construct roads until its physical and mechanical characteristics are determined. The main aim of this paper is, therefore, to determine the physical and mechanical characteristics of MSWI bottom ash generated in the waste-to-energy plant in Klaipeda (Lithuania) and demonstrate the suitability of MSWI bottom ash for road construction.

\section{Requirements for municipal solid waste incinerator bottom ash utilization}

Municipal solid waste incinerator bottom ash consists of ash, ceramics, glass, minerals, ferrous and non-ferrous metals, unburned materials and organic carbon (Chandler et al., 1997; Chimenos, Segarra, Fernández, \& Espiell, 1999). Only some of MSWI bottom ash is allowed to use in civil engineering instead of landfilling, in view of the presence of heavy metals and soluble salts in bottom ash, which is harmful to the environment. As a result, leaching properties of bottom ash are crucial in deciding the possibility of MSWI bottom ash utilization.

According to chemical composition analysis of MSWI bottom ash the major compounds are $\mathrm{SiO}_{2}, \mathrm{Al}_{2} \mathrm{O}_{3}, \mathrm{Fe}_{2} \mathrm{O}_{3}$, and $\mathrm{CaO}$, whereas $\mathrm{MgO}, \mathrm{K}_{2} \mathrm{O}, \mathrm{Na}_{2} \mathrm{O}$, and $\mathrm{TiO}_{2}$ are in low concentrations (Bayuseno \& Schmahl, 2010; Lam, Ip, Barford, \& McKay, 2010; Qiao, Tyrer, Poon, \& Cheeseman, 2008; Speiser, Baumann, \& Niessner, 2000; Wei et al., 2011). A predominant compound in bottom ash is $\mathrm{SiO}_{2}$, which reaches up to $49 \%$ (Lam et al., 2010).

Seeking to reduce the leaching of metals, MSWI bottom ash is aged (weathered). It is a simple treatment for bottom ash when it is stored in the atmosphere with good access to water (e.g. in an uncovered stockpile). Metal oxides and hydrates that are present in the bottom ash react with carbon dioxide and water uptaken from the atmosphere and finally form carbonate. Furthermore, ageing transforms $\mathrm{Al}$ to stable $\mathrm{Al}_{2} \mathrm{O}_{3}$ and reduces hydrogen gas formation (Chandler et al., 1997). All these reactions stabilize MSWI bottom ash and lower $\mathrm{pH}$. Typical unaged bottom ash has a $\mathrm{pH}$ of about 11-12, which after ageing reduces to 8-10 $\mathrm{pH}$. The stabilization of bottom ash takes at least 1.5-6 months (Chandler et al., 1997; ISWA, 2006). Different countries apply different requirements for the minimum time of ageing. For example, in Spain, France, and Germany it is three months (del Valle-Zermeño, Chimenos, Giró-Paloma, \& Formosa, 2014; ISWA, 2006; Izquiedro et al., 2001), whereas in the Netherlands bottom ash can be aged only six weeks, and in Sweden it is extended up to six months (ISWA, 2006). According to the order by the Minister of Environment of the Republic of Lithuania, approved on 25 November 2016, bottom ash has to be aged at least three months if it is used in civil engineering. If bottom ash after minimum ageing has too high leaching of metals, the ageing duration is extended to further improve the quality of the bottom ash. Bottom ash without ageing can only be landfilled.

The other significant factor deciding the possibility of MSWI bottom ash utilization is a loss on ignition (LOI). A study in Denmark showed that LOI varies from less than $2 \%$ to $9 \%$ depending on the efficiency of the incineration process (Arm, 2003; Chandler et al., 1997; ISWA, 2006; Izquiedro et al., 2001). Modern waste-to-energy plants are capable of achieving low LOI. Sometimes it is even less than $2 \%$. 
Bottom ash contains about $7-15 \%$ of ferrous and $1-2 \%$ of non-ferrous metals (Baun, Kamuk, \& Avanzi, 2007; Sabbas et al., 2003). Ferrous metals constitute more than $60 \%$ of all metals. Non-ferrous metals consist of $\mathrm{Al}$, to the extent of over $60 \%, \mathrm{Cu}$ and precious metals, such as gold in small quantities (Grosso, Biganzoli, \& Rigamonti, 2011; Morf et al., 2013). The recovery of both ferrous and nonferrous metals is a significant step in reducing the negative effect on the environment and increasing the suitability of bottom ash for use in civil engineering. Besides, it yields economic benefits since recovered metals are recycled through the international scrap market. Typically, the recovery of ferrous metals, especially larger scrap, is common, with an efficiency exceeding $80 \%$, while non-ferrous metals are recovered to a considerably lesser extent (Heinrichs, Bastian, Alexander, \& Thomas, 2012). The conventional technology for the recovery of non-ferrous metals, i.e., eddy current separators, shows only $30 \%$ efficiency. However, over the last few decades, advanced recovery methods have been developed whereby efficiency even exceeds 70\% (Bakker, Muchová, \& Rem, 2007; de Vries \& Rem, 2013; de Vries, Rem, \& Berkhout, 2009; Grosso et al., 2011). The technique selected for metals recovery leads to specific fractions of bottom ash that is used separately or mixed with each other, depending on what gradation of bottom ash is required.

Some countries have additional general requirements for bottom ash utilization in civil engineering. For example, Denmark does not permit the use of bottom ash near sources of drinking water and below the groundwater table. Besides, it has always been paved (ISWA, 2006). In France, the use of bottom ash in the construction of embankments is subject to the requirement that its thickness is less than $3 \mathrm{~m}$ and that it is protected by a plant cover (ISWA, 2006; Triffault-Bouchet, Clément, \& Blake, 2005). In general, different standards prevail in different countries concerning leaching methods and thresholds for bottom ash utilization, allowable LOI, and metals in bottom ash.

\section{Experimental research}

\subsection{Materials}

All bottom ash samples were selected from the waste-toenergy plant in Klaipeda (Lithuania) (Figure 1). Currently, in Lithuania, only one MSWI is open, but two other plants in Kaunas and Vilnius will be opened in 2019. According to the data provided by a state-owned energy company (Lietuvos Energija Group), it will result in 2.3 times more bottom ash (175 000 tonnes per year) compared to the situation in 2018.

Ferrous and non-ferrous metals from analysed bottom ash were recovered after more than 3 months of MSWI bottom ash ageing in the atmosphere (Figure 2). The metals recovery technique resulted in the following fractions of bottom ash: 0/2, 2/4, 4/8, 5/11 and 11/22 (Figure 3).

\subsection{Methods}

An experimental plan (Figure 4) to investigate the suitability of MSWI bottom ash as an aggregate for road building materials was designed based on a literature review and Lithuanian requirements for road construction. It consisted of two stages: the first stage concerned bottom ash as aggregate analysis, and the second as aggregate mixtures for subgrade, sub-base, and base layers. In the first stage five separate bottom ash fractions $(0 / 2,2 / 4,4 / 8,5 / 11$ and 11/22), which are the results after recovery of metals, were tested and analysed. For each of them the physical and mechanical characteristics, which are listed here, were determined:

- aggregate particle size distribution (LST EN 933-1 Tests for geometrical properties of aggregates - Part 1: Determination of particle size distribution - Sieving method);

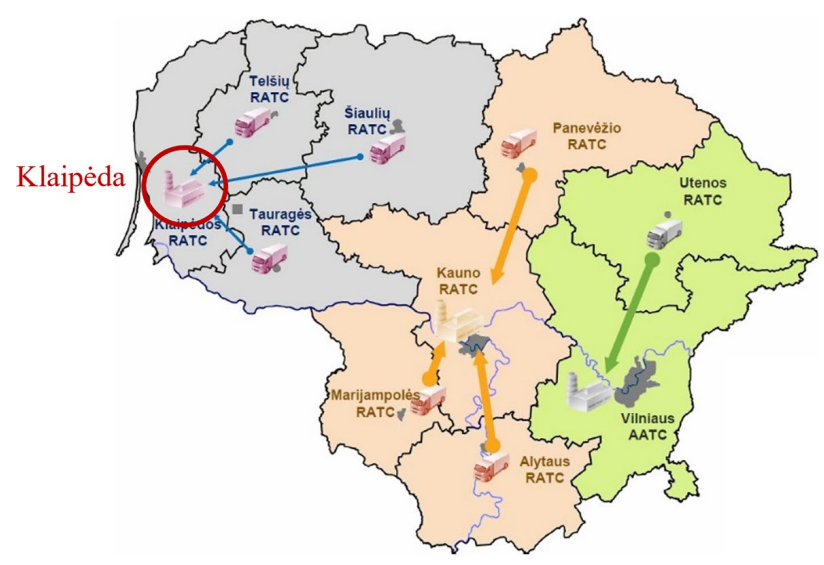

Figure 1. Explication of waste supply and MSWI distribution in the Republic of Lithuania

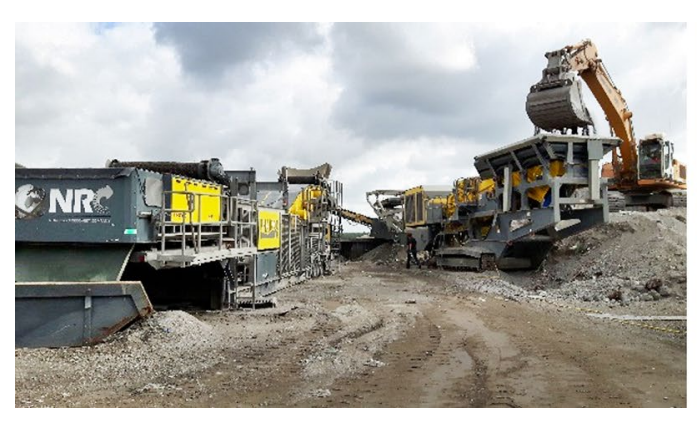

Bottom ash is supplied to metals recovery system

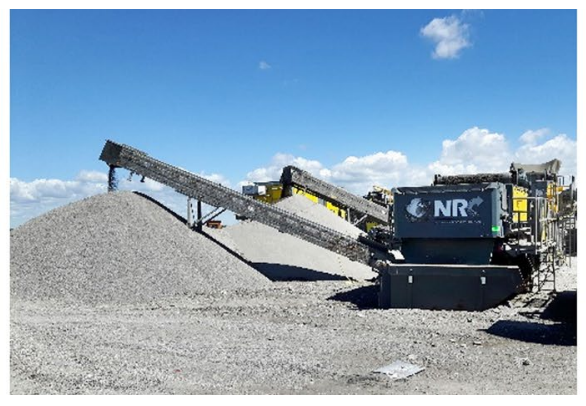

Bottom ash after metals recovery

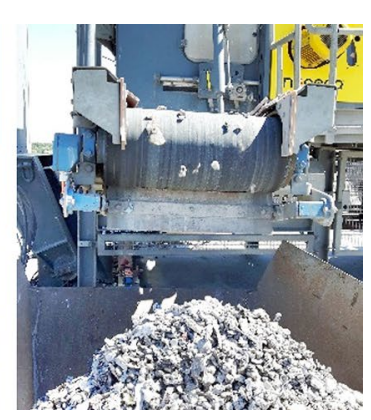

Recovered ferrous metals

Figure 2. Metals recovery 
- water content (LST EN 1097-5 Tests for mechanical and physical properties of aggregates - Part 5: Determination of the water content by drying in a ventilated oven);

- oven-dried particle density and water absorption (LST EN 1097-6 Tests for mechanical and physical properties of aggregates - Part 6: Determination of particle density and water absorption);

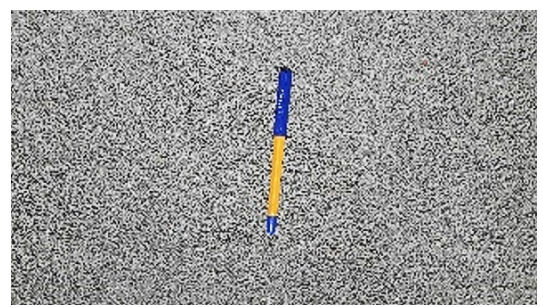

Fraction $0 / 2$

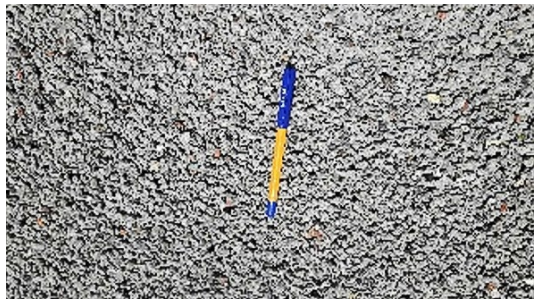

Fraction $2 / 4$

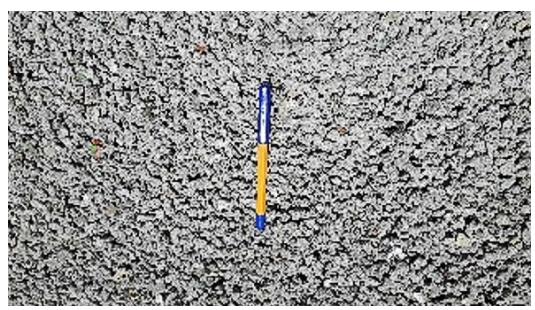

Fraction $4 / 8$

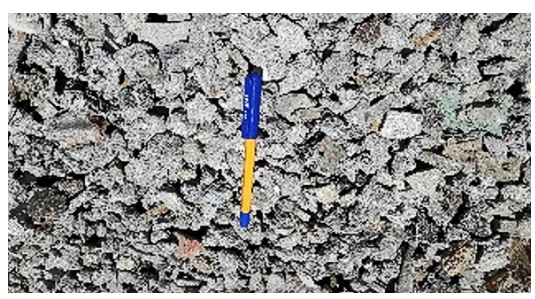

Fraction 5/11

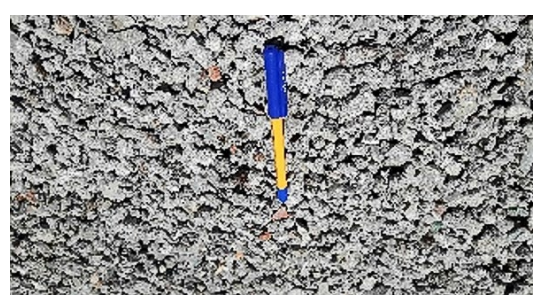

Fraction $11 / 22$

Figure 3. Bottom ash after metals recovery
- loose bulk density (LST EN 1097-3 Tests for mechanical and physical properties of aggregates - Part 3: Determination of loose bulk density and voids);

- Flakiness Index (FI) (LST EN 933-3 Tests for geometrical properties of aggregates - Part 3: Determination of particle shape - Flakiness index);

- Shape Index (SI) (LST EN 933-4 Tests for geometrical properties of aggregates - Part 4: Determination of particle shape - Shape index);

- percentage of crushed and broken surfaces (LST EN 933-5 Tests for geometrical properties of aggregates Part 5: Determination of percentage of crushed and broken surfaces in coarse aggregate particles);

- resistance to fragmentation (LA) (LST EN 1097-2 Tests for mechanical and physical properties of aggregates - Part 2: Methods for the determination of resistance to fragmentation);

- resistance to freezing and thawing (LST EN 1367-1 Tests for thermal and weathering properties of aggregates - Part 1: Determination of resistance to freezing and thawing and German method);

- permeability (LST CEN ISO/TS 17892-11 Geotechnical investigation and testing - Laboratory testing of soil - Part 11: Determination of permeability by constant and falling head);

- Proctor density and optimal water content (LST EN 13286-2 Unbound and hydraulically bound mixtures Part 2: Test methods for laboratory reference density and water content - Proctor compaction);

- CBR before and after $96 \mathrm{~h}$ of soaking (LST EN 1328647 Unbound and hydraulically bound mixtures - Part 47: Test method for the determination of California bearing ratio, immediate bearing index and linear swelling).

To determine each of the listed characteristics seven specimens were prepared and tested, except water content, for which only one specimen was tested.

As the methods for aggregates (mixtures) resistance to freezing vary within the countries, the German method was applied for the $0 / 2$ fraction and the standard procedure according to LST EN 1367-1 for all of them. The German method to determine resistance to freezing and thawing, which is applied only for MSWI bottom ash and other recycled building materials, is very similar to the standard procedure according to LST EN 1367-1. The main difference is that in the German method mixtures $(0 / 8,0 / 11$, $0 / 16,0 / 22$ ) are tested, and after 10 freeze-thaw cycles the focus is concentrated on the amount of particles smaller than $0.063 \mathrm{~mm}$. The whole amount of particles smaller than $0.063 \mathrm{~mm}$ in the tested mixture is calculated by adding the initial (before the test) and the final (after test) amount of particles smaller than $0.063 \mathrm{~mm}$. According to German requirements, the mixture is resistant to freezing and thawing if after 10 freeze-thaw cycles the amount of particles smaller than $0.063 \mathrm{~mm}$ in the tested mixture is not more than $2 \%$ and the whole amount of particles smaller than $0.063 \mathrm{~mm}$ (before and after the test) does not exceed 9\%. European standards require that specific 


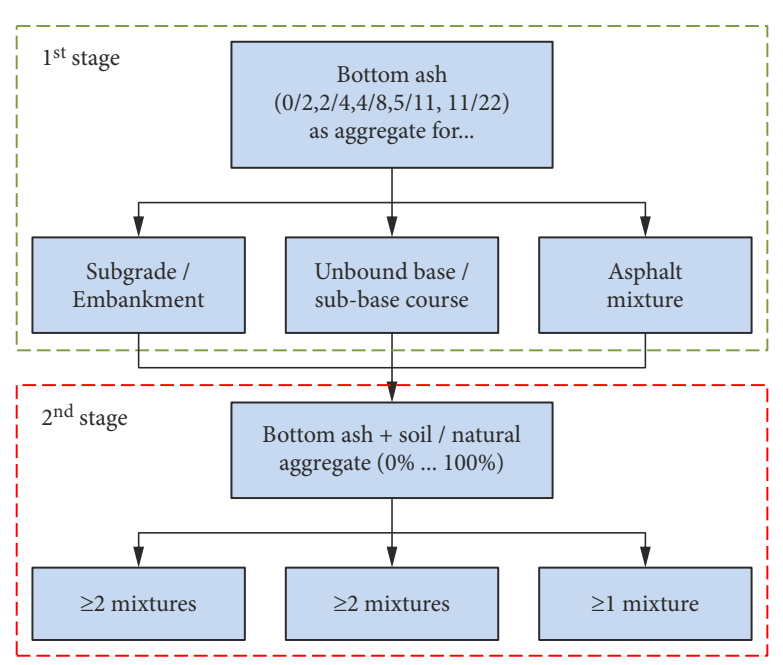

Figure 4. Experimental plan

fractions $(4 / 8,8 / 16,16 / 32$ and 32/63) be tested and after the test the amount of particles smaller than half the lower size sieve used to prepare the test specimen (e.g. in the case of $8 / 16$ a sieve of $4 \mathrm{~mm}$ size is used) is determined.

As the $0 / 2$ fraction is most susceptible to water absorption and has the lowest permeability, Proctor density, optimal water content and CBR were determined only for this fraction of bottom ash.

This stage is crucial for bottom ash utilisation in road construction since, according to Lithuanian technical and normative legislation documents, each recycled material and its fraction that is used to produce mixtures for subgrade, embankment, unbound base/sub-base courses or asphalt mixtures has to comply with the requirements for the utilisation purpose, e.g. graduation, FI, SI, LA.

In the second stage of the experimental plan, different mixtures are analysed, made of different fractions of bottom ash or bottom ash mixed with soil and natural aggregates. All components are mixed in different proportions so that compliance with requirements for aggregate gradation depending on utilization purpose (subgrade, embankment, unbound base/sub-base course or asphalt mixture) and specific characteristics are determined. The result of this stage is products (mixtures) that satisfy Lithuanian requirements and are suitable to construct subgrade, embankment, unbound base/sub-base courses and produce asphalt mixtures. At least five mixtures comprising bottom ash will be designed after full implementation of the experimental plan.

This paper presents the results only of the first stage of the experimental plan.

\section{Results and discussions}

The physical and mechanical characteristics that were determined in respect of the five bottom ash fractions $(0 / 2$, $2 / 4,4 / 8,5 / 11$ and 11/22) are given in Figures 5-13. Error bars in the graphs represent the minimum and maximum values. If a characteristic of any fraction is not given, it means that this characteristic cannot be determined for this specific fraction according to the test standard. Table 1 presents the characteristics determined for the $0 / 2$ fraction of bottom ash.

Figures 6-13 and Table 1 reveal a low variability of bottom ash characteristics among different measures. The coefficient of variation is lower than $10 \%$ independently of the bottom ash fraction and characteristic except the flakiness index for the 11/22 fraction, the shape index for the $5 / 11$ and 11/22 fractions, resistance to freezing and thawing for the $2 / 4$ and $5 / 11$ fractions, permeability and CBR. The coefficient of variation of these characteristics and fractions is lower than $31 \%$. The most variable characteristic is permeability. The coefficient of variation is $30.65 \%$. The material consistency is one of the most important factors considering its utilization in road construction.

Table 2 presents a summary of the characteristics of bottom ash and the Lithuanian requirements for road materials. According to Lithuanian technical and normative legislation documents, the material used for subgrade and embankments construction has to ensure high compaction and sufficient bearing capacity. However, the specific requirements are not given in normative documents. Consequently, the requirements for only two of three application purposes are given in Table 2.

Characteristics of bottom ash fractions were compared to the requirements for the materials used to produce asphalt mixture or construct unbound sub-base and base course. It showed promising results considering bottom ash utilization as road building material. Almost all characteristics of bottom ash fractions complied with the requirements. The main issue is related to bottom ash susceptibility to frost. All fractions of bottom ash failed in the requirements for frost blanket course and asphalt mixture according to water absorption and resistance to freezing and thawing determined by both European and German methods. Thus, bottom ash cannot be used to construct frost blanket course and produce asphalt mixture, however, it is suitable to produce a mixture of layers of frostresistant material and unbound base course.

Regarding unbound base course, it can be constructed of crushed stone and gravel. If recycled materials are used to construct a base course of crushed stone, LA cannot be higher than 35 . Only $2 / 4$ fraction of bottom ash complied with this requirement.

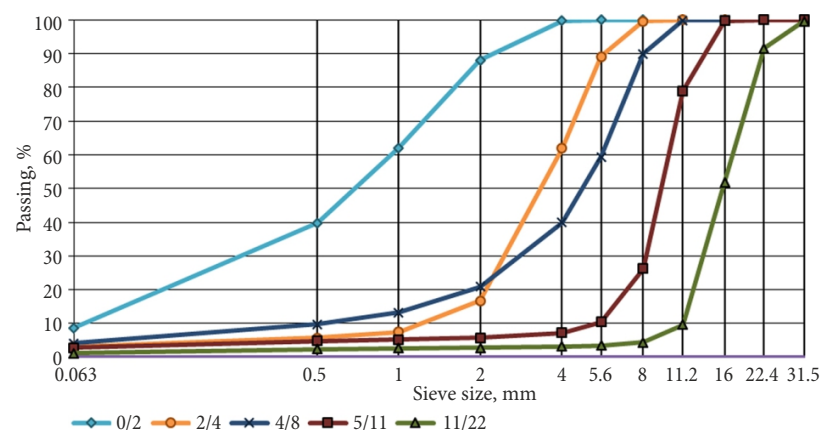

Figure 5. Bottom ash particle size distribution 


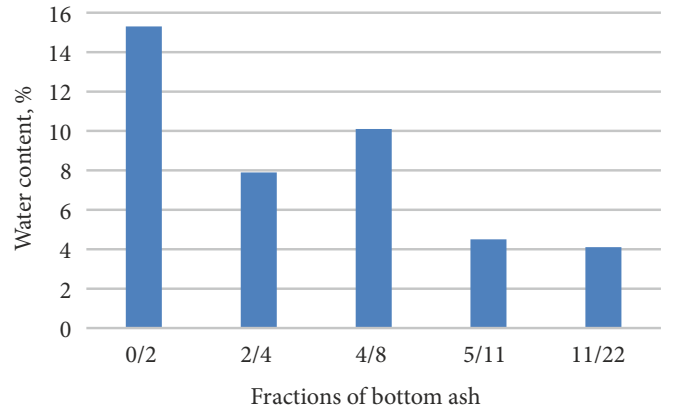

Figure 6. Water content

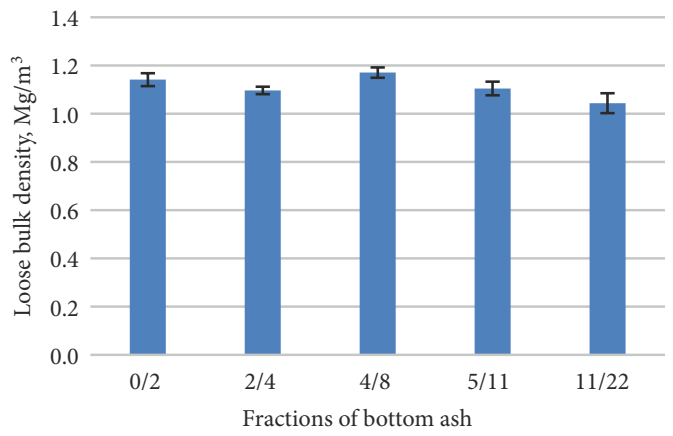

Figure 8. Loose bulk density

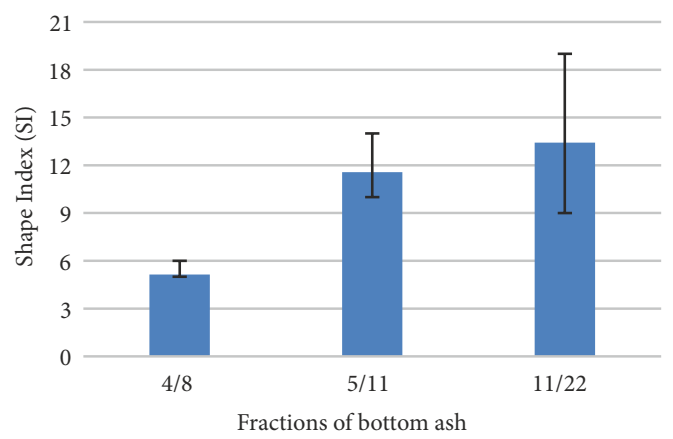

Figure 10. Shape Index

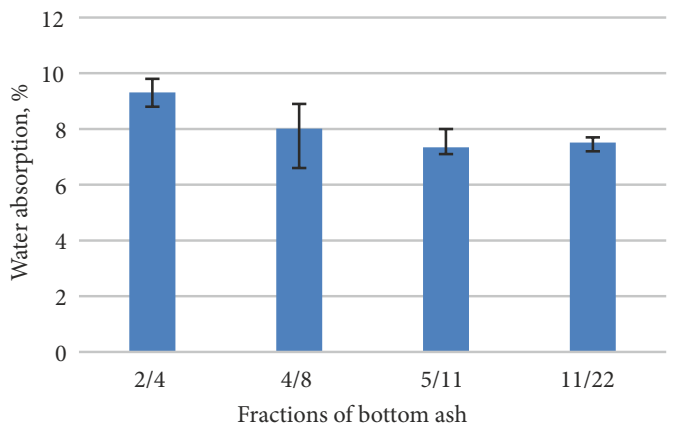

Figure 12. Water absorption

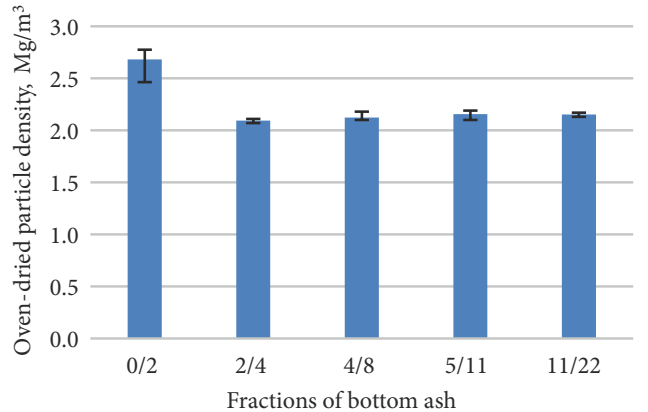

Figure 7. Oven-dried particle density

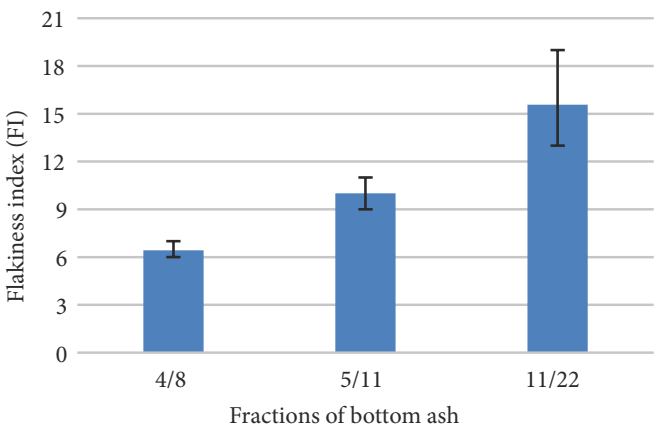

Figure 9. Flakiness Index (FI)

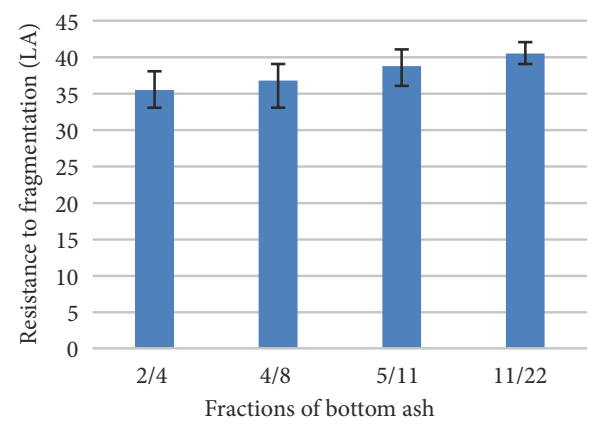

Figure 11. Resistance to fragmentation

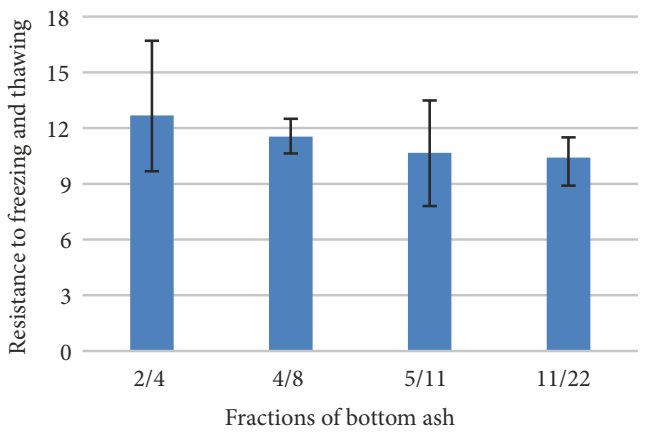

Figure 13. Resistance to freezing and thawing 
Table 1. Characteristics determined for $0 / 2$ fraction of bottom ash

\begin{tabular}{|c|c|c|c|c|c|c|c|c|}
\hline \multirow{3}{*}{ Parameter } & \multicolumn{8}{|c|}{ Characteristic } \\
\hline & \multirow{2}{*}{$\begin{array}{l}\text { Permeability, } \\
\cdot 10^{-5} \mathrm{~m} / \mathrm{s}\end{array}$} & \multirow{2}{*}{$\begin{array}{l}\text { Proctor } \\
\text { density, } \\
\mathrm{Mg} / \mathrm{m}^{3}\end{array}$} & \multirow{2}{*}{$\begin{array}{c}\text { Optimal } \\
\text { water content, } \\
\%\end{array}$} & \multirow{2}{*}{$\begin{array}{l}\text { CBR before } \\
\text { soaking, } \%\end{array}$} & \multirow{2}{*}{$\begin{array}{l}\mathrm{CBR} \text { after } 96 \mathrm{~h} \text { of } \\
\text { soaking, } \%\end{array}$} & \multicolumn{3}{|c|}{$\begin{array}{l}\text { Resistance to freezing and thawing } \\
\qquad(<0.063 \mathrm{~mm})^{*}, \%\end{array}$} \\
\hline & & & & & & $\begin{array}{l}\text { before } \\
\text { the test }\end{array}$ & $\begin{array}{l}\text { after } \\
\text { the test }\end{array}$ & sum \\
\hline Min & 4.32 & 1.47 & 20.0 & 28.7 & 17.2 & 8.00 & 2.40 & 10.40 \\
\hline Max & 10.9 & 1.59 & 23.0 & 41.4 & 37.8 & 9.24 & 3.59 & 12.32 \\
\hline Average & 7.39 & 1.51 & 20.9 & 36.2 & 30.3 & 8.43 & 3.02 & 11.45 \\
\hline
\end{tabular}

Note: ${ }^{*}$ German method, in which amount of particles smaller than $0.063 \mathrm{~mm}$ in tested mixture is determined.

Table 2. Summary of the characteristics of bottom ash and the Lithuanian requirements for road materials

\begin{tabular}{|c|c|c|c|c|c|c|c|c|}
\hline \multirow[b]{2}{*}{ Characteristic } & \multicolumn{5}{|c|}{ Bottom ash fraction } & \multicolumn{3}{|c|}{ Requirements for materials used for } \\
\hline & $0 / 2$ & $2 / 4$ & $4 / 8$ & $5 / 11$ & $11 / 22$ & $\begin{array}{l}\text { Unbound sub- } \\
\text { base course }\end{array}$ & $\begin{array}{l}\text { Unbound } \\
\text { base course }\end{array}$ & $\begin{array}{l}\text { Asphalt mixture } \\
\text { (AC } 16 \mathrm{PD})\end{array}$ \\
\hline Water content, $\%$ & 15.3 & 7.9 & 10.1 & 4.5 & 4.1 & - & - & - \\
\hline $\begin{array}{l}\text { Oven-dried particle density, } \\
\mathrm{Mg} / \mathrm{m}^{3}\end{array}$ & 2.682 & 2.093 & 2.123 & 2.156 & 2.152 & Declared & Declared & Declared \\
\hline Loose bulk density, $\mathrm{Mg} / \mathrm{m}^{3}$ & 1.141 & 1.097 & 1.171 & 1.105 & 1.044 & - & - & - \\
\hline Flakiness Index (FI), - & - & - & 6 & 10 & 16 & $\mathrm{FI}_{50}$ & $\mathrm{FI}_{50}$ & $\mathrm{FI}_{50}$ \\
\hline Shape Index (SI), - & - & - & 5 & 12 & 13 & $\mathrm{SI}_{55}$ & $\mathrm{SI}_{55}$ & $\mathrm{SI}_{50}$ \\
\hline $\begin{array}{l}\text { Percentage of crushed and broken } \\
\text { surfaces }\end{array}$ & - & - & $\mathrm{C}_{96 / 2}$ & $\mathrm{C}_{97 / 2}$ & $\mathrm{C}_{96 / 1}$ & $\mathrm{C}_{\mathrm{NR}}$ & $\mathrm{C}_{90 / 3}^{4)}$ & $\mathrm{C}_{\mathrm{NR}}^{5)}, \mathrm{C}_{50 / 30}$ \\
\hline Resistance to fragmentation (LA), - & - & 35 & 37 & 39 & 40 & $\mathrm{LA}_{40}{ }^{6)}$ & $\left.\mathrm{LA}_{40} 6,7\right)$ & $\mathrm{LA}_{40}{ }^{6)}$ \\
\hline Water absorption, $\%$ & - & 9.3 & 8.0 & 7.3 & 7.5 & $\mathrm{~W}_{\mathrm{cm}} 0.5$ & $\mathrm{~W}_{\mathrm{cm}} 0.5$ & $\mathrm{~W}_{\mathrm{cm}} 0.5$ \\
\hline $\begin{array}{l}\text { Resistance to freezing and thawing } \\
(\text { loss mass })^{1)}, \%\end{array}$ & - & 12.7 & 11.5 & 10.7 & 10.4 & $\mathrm{~F}_{4}$ & $\mathrm{~F}_{\text {Declared }}^{8)}$ & $\mathrm{F}_{1}$ \\
\hline $\begin{array}{l}\text { Resistance to freezing and thawing } \\
(<0.063 \mathrm{~mm} \text { after test })^{2)}, \%\end{array}$ & 3.02 & - & - & - & - & $\leq 2^{2)}$ & - & - \\
\hline $\begin{array}{l}\text { Resistance to freezing and thawing } \\
(<0.063 \mathrm{~mm} \text { sum of before and } \\
\text { after test })^{2)}, \%\end{array}$ & 11.45 & - & - & - & - & $\leq 9^{2}$ & - & - \\
\hline Permeability, $\cdot 10^{-5} \mathrm{~m} / \mathrm{s}$ & 7.39 & - & - & - & - & $\geq 2.0$ & - & - \\
\hline Proctor density, $\mathrm{Mg} / \mathrm{m}^{3}$ & 1.509 & - & - & - & - & - & - & - \\
\hline Optimal water content, $\%$ & 20.9 & - & - & - & - & - & - & - \\
\hline CBR before soaking, $\%$ & 36.2 & - & - & - & - & - & - & - \\
\hline CBR after $96 \mathrm{~h}$ of soaking, \% & 30.3 & - & - & - & - & - & - & - \\
\hline
\end{tabular}

Notes: ${ }^{1)}$ Resistance to freezing and thawing is determined according to LST EN $1367-1 ;{ }^{2}$ Resistance to freezing and thawing is determined according to the German method. The threshold is also adapted from Germany; ${ }^{3}$ In Lithuania unbound sub-base course has to be resistant to frost and is called a frost blanket course or layer of frost-resistant material depending on materials characteristics. This table gives the requirements for materials used in frost blanket course, since materials used in the layer of frost resistant material are not regulated; ${ }^{4}$ This requirement is only for base course of crushed stone; ${ }^{5}$ Material that passes this category can be used only if a producer has a long-term positive practice regarding the utilisation; ${ }^{6}$ This requirement depends on what kind of material is used. $\mathrm{LA}_{40}$ is for recycled materials; ${ }^{7)}$ If recycled materials are used to construct a base course of crushed stone, LA cannot be higher than $35 ;{ }^{8)}$ This requirement is valid only for recycled materials.

Since bottom ash revealed more than 3 times better permeability than is required for the most significant roads and in most cases it will be used on roads with low traffic volume, its suitability for frost blanket course should be reconsidered despite its susceptibility to frost.

The characteristics of bottom ash fractions were also compared to those of natural sand and gravel. MSWI bot- tom ash is a lighter building material since oven-dried particle density and loose bulk density are 15-20\% lower. It was also noticed that the $0 / 2$ fraction of bottom ash is significantly denser than other fractions of bottom ash. Besides, it has the highest water content. The water content of bottom ash decreases concerning bigger particle size because small particles accumulate more water than 
coarser particles do. The flakiness index and shape index of bottom ash is similar to that of natural sand and gravel and increase with a coarser fraction of bottom ash. However, bottom ash is less resistant to both fragmentation and freezing and thawing. LA of bottom ash is $15-40 \%$ worse than that of natural sand and gravel. Besides, natural sand and gravel have low water absorption and usually pass the $F_{1}$ category according to resistance to freezing and thawing. The $0 / 2$ fraction of bottom ash revealed that CBR (36.2\%) is similar to that of sand (SW and SM) and gravel (GC). After 96 hours of soaking, CBR decreased only $16 \%$. It is believed that coarser fractions of bottom ash will show even better results of CBR. Thus, there is no doubt about the suitability of bottom ash for subgrade and embankment. Besides, the results agree with those of other researchers who demonstrated the suitability of bottom ash for the unbound base and sub-base course according to CBR (Forteza et al., 2004; Izquiedro et al., 2001).

\section{Conclusions}

1. The utilisation of municipal solid waste incinerator bottom ash is a key issue in moving towards less landfilling, and in Lithuania it becomes even more important because 2.3 times more bottom ash will be generated annually consequent on a dramatic increase in the production of municipal solid waste incinerator bottom ash (in general about 175000 tonnes per year) after two new waste-to-energy plants are opened in 2019.

2. Two main items, first, environmental (leaching properties of bottom ash, metals content of bottom ash, loss on ignition), and, second, technical and technological (conformity with the regulation of legal technical documents for road building materials), characterise the possibility to use municipal solid waste incinerator bottom ash in construction, especially of roads. Ageing (weathering) for at least 3 months and recovery of ferrous and non-ferrous metals are essential procedures to reduce the negative effect of bottom ash on the environment. Bottom ash without these procedures cannot be used for construction, i.e. it has to be landfilled.

3. Physical and mechanical characteristics (except water absorption and resistance to freezing and thawing) of bottom ash fractions $(0 / 2,2 / 4,4 / 8,5 / 11$ and $11 / 22$ ) produced after more than three months of municipal solid waste incinerator bottom ash ageing in the atmosphere and recovery of ferrous and nonferrous metals met the requirements for aggregate of road building materials. Thus, bottom ash can be successfully used for subgrade and embankment, to produce mixtures for subbase and base course as gravel substitute. Only 2/4 fraction of bottom ash complies with Los Angeles value required for crushed aggregate base layer, Los Angeles value up to 35. The tendency for Los Angeles value to de- crease with the bottom ash particle size increase was observed, the loves $\mathrm{LA}_{35}-2 / 4$ fraction, the highest $\mathrm{LA}_{45}-11 / 22$.

4. Bottom ash suitability to produce asphalt mixtures is doubtful because of its large susceptibility to freezing and thawing. According to this research, only the $0 / 2$ fraction of bottom ash may be used to produce asphalt mixtures; however, a thorough investigation is needed.

5. Bottom ash suitability for frost blanket course should be reconsidered despite its susceptibility to frost. Though it revealed more than three times better permeability than is required $\left(\geq 2 \cdot 10^{-5} \mathrm{~m} / \mathrm{s}\right)$ for the main roads. An experimental road sections have to be constructed to clarify frost resistance/susceptibility of frost blanket course with bottom ash aggregates in real traffic and environmental conditions.

6 . $76 \%$ of the determined characteristics of different fractions of bottom ash showed high consistency (coefficient of variation is lower than 10\%) independently of the fraction. The flakiness index for the $11 / 22$ fraction, shape index for the $5 / 11$ and $11 / 22$ fractions, resistance to freezing and thawing for the 2/4 and 5/11 fractions, permeability and California Bearing Ratio for the $0 / 2$ fraction had the highest variability. The coefficient of variation of some of these characteristics and fractions reached up to $31 \%$.

7. The requirements for the utilization of bottom ash for roads with a large number of equivalent single axle loads have to be established since bottom ash has lower characteristics than typical building materials (e.g. natural sand, gravel).

8. It is essential to conduct the second part of the experimental plan to reasonably determine the performance of subgrade and unbound/bound road pavement structure layers with bottom ash as the main aggregate in road building materials. In this part, mixtures made of bottom ash and soil or natural aggregate (0-100\%) will be designed and analysed.

\section{Acknowledgements}

This study was funded by a private limited liability company, "Fortum Heat Lietuva".

\section{References}

Alhassan, H. M., \& Tanko, A. M. (2012). Characterization of solid waste incinerator bottom ash and the potential for its use. International Journal of Engineering Research and Applications, 2(4), 516-522.

An, J., et al. (2014). Evaluating the use of waste-to-energy bottom ash as road construction materials. Report No. BDK78-97720. Orlando: University of Central Florida.

Arm, M. (2003). Mechanical properties of residues as unbound road materials: Doctoral thesis. Stockholm: Royal Institute of Technology. 
Bayuseno, A. P., \& Schmahl, W. W. (2010). Understanding the chemical and mineralogical properties of the inorganic portion of MSWI bottom ash. Waste Management, 30(8/9), 15091520. https://doi.org/10.1016/j.wasman.2010.03.010

Bakker, E. J., Muchová, L., \& Rem, P. C. (2007). Economic recovery of precious metals from MSWI bottom ash. 1st International Conference on Environmental Management, Engineering, Planning and Economics (CEMEPE 2007) (pp. 1-5). Skiathos Island, Greece.

Baun, D., Kamuk, B., \& Avanzi, P. (2007). Treatment of bottom ash from waste to energy plants: overview and experiences. 11th International Waste Management and Landfill Symposium (pp. 1-5). October, Cagliari.

Becquart, F., Bernard, F., Abriak, N.-E., \& Zentar, R. (2009). Monotonic aspects of the mechanical behaviour of bottom ash from municipal solid waste incineration and its potential use for road construction. Waste Management, 29(4), 13201329. https://doi.org/10.1016/j.wasman.2008.08.019

Chandler, A. J., et al. (1997). Municipal solid waste incinerator residues. Studies in Environmental Science, 67, 1-974.

Chimenos, J., Segarra, M., Fernández, M. A., \& Espiell, F. (1999). Characterization of the bottom ash in municipal solid waste incinerator. Journal of Hazardous Materials, 64(3), 211-222. https://doi.org/10.1016/S0304-3894(98)00246-5

de Vries, W., \& Rem, P. C. (2013). ADR: a classifier for fine moist materials. In V. Gente \& F. La Marca (Eds.), Separating pro-environment technologies for waste treatment, soil and sediments remediation (pp. 43-58). Sharjah, UAE: Bentham Science Publishers. Retrieved from http://www.eurekaselect. com/104898/volume/1.

de Vries, W., Rem, P. C., \& Berkhout, S. P. M. (2009). ADR: A new method for dry classification. ISWA International Conference, Lisbon, 12-15 October 2009. Retrieved from http:// www.iswa2009.org/homepage.aspx.

del Valle-Zermeño, R., Chimenos, J. M., Giró-Paloma, J., \& Formosa, J. (2014). Use of weathered and fresh bottom ash mix layers as a subbase in road constructions: environmental behavior enhancement by means of a retaining barrier. Chemosphere, 117(1), 402-409. https://doi.org/10.1016/j.chemosphere.2014.07.095

Forteza, R., Far, M., Seguí, C., \& Cerdá, V. (2004). Characterization of bottom ash in municipal solid waste incinerators for its use in road base. Waste Management, 24(9), 899-909. https://doi.org/10.1016/j.wasman.2004.07.004

Grosso, M., Biganzoli, L., \& Rigamonti, L. (2011). A quantitative estimate of potential aluminium recovery from incineration bottom ashes. Resources, Conservation and Recycling, 55(12), 1178-1184. https://doi.org/10.1016/j.resconrec.2011.08.001

Hassan, H. F., \& Al-Shamsi, K. (2010). Characterisation of asphalt mixes containing MSW ash using the Dynamic Modulus $\left|\mathrm{E}^{*}\right|$ test. International Journal of Pavement Engineering, 11(6), 575-582. https://doi.org/10.1080/10298436.2010.501865

Heinrichs, S., Bastian, W., Alexander, F., \& Thomas, P. (2012). Recovery of nf-metals from bottom ash's fine fraction - stateof-the-art in Germany. 4th International Symposium on Energy from Biomass and Waste (pp. 12-15), November 2012. San Servolo, Venice, Italy.

Hjelmar, O., Holm, J., \& Crillesen, K. (2007). Utilisation of MSWI bottom ash as sub-base in road construction: first results from a large-scale test site. Journal of Hazardous Materials, 139(3), 471-480. https://doi.org/10.1016/j.jhazmat.2006.02.059

ISWA. (2006). Management of bottom ash from WTE plants. Copenhagen: ISWA.
Izquiedro, M., et al. (2001). Use of bottom ash from municipal solid waste incineration as a road material. International Ash Utilization Symposium (pp. 1-8). Center for Applied Energy Research, University of Kentucky.

Lam, C. H. K., Ip, A. W. M., Barford, J. P., \& McKay, G. (2010). Use of incineration MSW ash: a review. Sustainability, 2(7), 1943-1968. https://doi.org/10.3390/su2071943

LST CEN ISO/TS 17892-11 Geotechnical investigation and testing - Laboratory testing of soil - Part 11: Determination of permeability by constant and falling head.

LST EN 1097-2 Tests for mechanical and physical properties of aggregates - Part 2: Methods for the determination of resistance to fragmentation.

LST EN 1097-3 Tests for mechanical and physical properties of aggregates - Part 3: Determination of loose bulk density and voids.

LST EN 1097-5 Tests for mechanical and physical properties of aggregates - Part 5: Determination of the water content by drying in a ventilated oven.

LST EN 13286-2 Unbound and hydraulically bound mixtures Part 2: Test methods for laboratory reference density and water content - Proctor compaction.

LST EN 13286-47 Unbound and hydraulically bound mixtures Part 47: Test method for the determination of California bearing ratio, immediate bearing index and linear swelling.

LST EN 1367-1 Tests for thermal and weathering properties of aggregates - Part 1: Determination of resistance to freezing and thawing and German method.

LST EN 933-3 Tests for geometrical properties of aggregates - Part 3: Determination of particle shape - Flakiness index.

LST EN 933-4 Tests for geometrical properties of aggregates - Part 4: Determination of particle shape - Shape index.

LST EN 933-5 Tests for geometrical properties of aggregates - Part 5: Determination of percentage of crushed and broken surfaces in coarse aggregate particles.

LST EN 1097-6 Tests for mechanical and physical properties of aggregates - Part 6: Determination of particle density and water absorption.

Morf, L. S., et al. (2013). Precious metals and rare earth elements in municipal solid waste - sources and fate in a Swiss Incineration plant. Waste Management, 33(3), 634-644. https://doi.org/10.1016/j.wasman.2012.09.010

Müller, U., \& Rübner, K. (2006). The microstructure of concrete made with municipal waste incinerator bottom ash as angregate component. Cement and Concrete Research, 36(8), 1434-1443. https://doi.org/10.1016/j.cemconres.2006.03.023

Ogunro, V. O., Inyang, H. I., Hooper, F., Young, D., \& Oturkar, A. (2004). Gradation control of bottom ash aggregate in superpave bituminous mixes. Journal of Materials in Civil Engineering, 16(6), 604-613.

https://doi.org/10.1061/(ASCE)0899-1561(2004)16:6(604)

Paine, K. A., Dhir, R. K., Doran, V. P. A. (2002). Incinerator bottom ash: engineering and environmental properties as a cement bound paving material. International Journal of Pavement Engineering, 3(1), 43-52.

https://doi.org/10.1080/10298430290023458

Pecqueur, G., Crignon, C., \& Quénée, B. (2001). Behaviour of cement-treated MSWI bottom ash. Waste Management, 21(3), 229-233. https://doi.org/10.1016/S0713-2743(00)80065-3

Qiao, X. C., Tyrer, M., Poon, C. S., \& Cheeseman, C. R. (2008). Novel cementitious materials produced from incinerator bottom ash. Resources, Conservation and Recycling, 52(3), 496510. https://doi.org/10.1016/j.resconrec.2007.06.003 
Sabbas, T., et al. (2003). Management of municipal solid waste incineration residues. Waste Management, 23(1), 61-88. https://doi.org/10.1016/S0956-053X(02)00161-7

Sorlini, S., Abbà, A., \& Collivignarelli, C. (2011). Recovery of MSWI and soil washing residues as concrete aggregates. Waste Management, 31(2), 289-297.

https://doi.org/10.1016/j.wasman.2010.04.019

Speiser, C., Baumann, T., \& Niessner, R. (2000). Morphological and chemical characterization of calcium-hydrate phases formed in alteration processes of deposited municipal solid waste incinerator bottom ash. Environmental Science \& Technology, 34(23), 5030-5037. https://doi.org/10.1021/es990739c

Triffault-Bouchet, G., Clément, B., \& Blake, G. (2005). Ecotoxicological assessment of pollutant flux released from bottom ash reused in road construction. Aquatic Ecosystem Health \& Management, 8(4), 405-414.

https://doi.org/10.1080/14634980500457724

Wei, Y., et al. (2011). Mineralogical characterization of municipal solid waste incineration bottom ash with an emphasis on heavy metal-bearing phases. Journal of Hazardous Materials, 187(1-3), 534-543.

https://doi.org/10.1016/j.jhazmat.2011.01.070

Xie, R., et al. (2017). Assessment of municipal solid waste incineration bottom ash as a potential road material. Road Materials and Pavement Design, 18(4), 992-998.

https://doi.org/10.1080/14680629.2016.1206483 